Tropical Journal of Pharmaceutical Research October 2016; 15 (10): 2071-2076

ISSN: $1596-5996$ (print); 1596-9827 (electronic)

(C) Pharmacotherapy Group, Faculty of Pharmacy, University of Benin, Benin City, 300001 Nigeria.

All rights reserved.

Available online at http://www.tjpr.org

Original Research Article

http://dx.doi.org/10.4314/tjpr.v15i10.3

\title{
Bryostatin I inhibits growth and proliferation of pancreatic cancer cells via suppression of NF-KB activation
}

\author{
Xiao-Bin Peng, Gao-Jue Wu, Xiao-Yu Wang, Xue-Jun Tang, Lei Gong* \\ Department of Gastroenterology, Wuxi No. 2 Hospital Affiliated to Nanjing Medical University, Wuxi 214000, China
}

*For correspondence: Email: gonglei186@hotmail.com; Tel/Fax: 0086-510-66681222

Received: 15 September 2015

Revised accepted: 7 September 2016

\begin{abstract}
Purpose: To evaluate the effect of bryostatin I on proliferation of pancreatic cancer cells as well as tumor growth in mice tumor xenograft model.

Methods: Activation of NF-KB was evaluated by preparing nuclear material extract using nuclear extract kit (Carlsbad, CA, USA) followed by enzyme-linked immunosorbent assay (ELISA). Mice were injected with $3 \times 10^{5}$ MIApaCa 2 cells in $100 \mu \mathrm{L}$ volume of PBS. The animals in the treatment group were injected with $50 \mu \mathrm{g} / \mathrm{kg}$ of bryostatin 1 daily for 1 month in the morning whereas those in the untreated group received an equal volume of normal saline.

Results: Treatment of the MIApaCa 2 cells with bryostatin I caused a significant reduction in the activity of NF-KB in nucleoplasm ( $p=0.0002$ ). The increase in the concentration of bryostatin I from 10 to 50 $\mu M$ reduced MIApaCa 2 cell proliferation from 87 to $26 \%$. Bryostatin I treatment also led to increase in the proportion of cells in M1 phase with subsequent reduction in sub-G1 phase of cell cycle. Examination of the cell lysates revealed a higher expression level of cleaved caspase-8 in bryostatin Itreated MIApaCa 2 cells. Mean tumor diameter in the treatment and untreated groups was $5.34 \pm 2.16$ and $19.45 \pm 5.71 \mathrm{~mm}$, respectively, after 2 months of treatment $(p<0.0002)$. The mean weight of the tumors in the treatment and untreated groups was $123.67 \pm 22.56$ and $939.14 \pm 213.51 \mathrm{mg}$, respectively, after 2 months of treatment.

Conclusion: Bryostatin I inhibits growth and proliferation of pancreatic cancer through inhibition of NF$\kappa B$ expression, and therefore, needs to be further investigated for therapeutic application in pancreatic cancer.
\end{abstract}

Keywords: Bryostatin I, NF-KB expression, Proliferation, Apoptosis, Pancreatic cancer, Tumor volume

Tropical Journal of Pharmaceutical Research is indexed by Science Citation Index (SciSearch), Scopus, International Pharmaceutical Abstract, Chemical Abstracts, Embase, Index Copernicus, EBSCO, African Index Medicus, JournalSeek, Journal Citation Reports/Science Edition, Directory of Open Access Journals (DOAJ), African Journal Online, Bioline International, Open-J-Gate and Pharmacy Abstracts

\section{INTRODUCTION}

Pancreatic cancer is one of the most aggressive and common causes of deaths caused by cancer with a five year survival rate of less than $4 \%$ $[1,2]$. The characteristic features of the pancreatic carcinoma cells include high rate of proliferation and rapid invasive potential to adjacent tissues [3]. Pancreatic cancer because of no prominent symptoms is usually detected in its advanced stage which is a major hindrance to treatment strategies [4].
It is reported that in the regulation of cellular processes including, apoptosis, inflammation, and oncogenesis NF-kB has a vital role $[5,6]$. Therefore, suppression of NF-kB expression by various strategies has been found to be of great therapeutic importance for the treatment of cancers $[7,8]$. Enhanced expression of NF-KB was shown to correlate with aggressiveness of pancreatic cancer cell metastasis $[9,10]$. Activation of the factors involved in apoptosis has a great impact on the inhibition of the cancer cell 
proliferation and in turn carcinoma treatment [11]. $\mathrm{NF}-\mathrm{kB}$ is found in the cell cytoplasm in its inactive form, p50-p65 complex and p65-p105. Activation of NF-KB is induced by the phosphorylation of $I K B \alpha$ which then results in translocation of NF-KB to nucleus. Penetration of $\mathrm{NF}-\mathrm{KB}$ into the nucleus causes expression of the genes which initiate various activities such as induction of apoptosis and inflammation $[12,13]$.

Phytochemical investigation of the Bugula neritina and marine bryozoa has led to the isolation of 20 macrocyclic lactones known as bryostatins. Screening of these lactones against leukemia cell lines showed that these compounds possess potent cytotoxic activities [14]. Bryostatin I the most active compound is currently in phase II clinical trials for the treatment cancers [15-17]. In addition, bryostatin I treatment has been shown to promote the growth and proliferation of bone marrow progenitor cells [17]. Thus, bryostatin I treatment has overcome the disadvantages associated with the application of dangerous ionizing radiations [18]. The present study was aimed to investigate the effect of bryostatin I on pancreatic cancer cell proliferation and tumor xenograft mice model.

\section{EXPERIMENTAL}

\section{Reagents}

Bryostatin 1 and dimethyl sulphoxide (DMSO) were obtained from Sigma-Aldrich (St. Louis, MO, USA). Bryostatin 1 was dissolved in DMSO and stored under inert atmosphere at $-40^{\circ} \mathrm{C}$.

\section{Cell line and culture}

Human pancreatic carcinoma cell line, MIApaCa 2 was obtained from the American Type Culture Collection (Rockville, MD, USA). The cells were cultured in RPMI 1640 medium (Nissui Pharmaceutical Co., Ltd., Tokyo, Japan) containing $10 \%$ heat inactivated fetal bovine serum (JRH Biosciences, Lenexa, KS, USA), and antibiotics. The cells were maintained in a humidified atmosphere of $5 \% \mathrm{CO}_{2}$ at $37{ }^{\circ} \mathrm{C}$.

\section{Animals}

Thirty 8-week old mice, (BALBc nu/nu) were obtained from CLEA Japan Incorporated (Tokyo, Japan). All experiments involving animals were conducted in accordance with the National Institute of Health Guide for the Care and Use of Laboratory Animals [19]. All animal experiments were approved by the Ethics Committee of Wuxi No. 2 Hospital Affiliated to Nanjing Medical University (protocol no. FGS20131108). The mice were acclimatized to the laboratory atmosphere one week before the start of actual experiment. All the mice were caged and housed in the rooms with $12 \mathrm{~h}$ light and dark cycle at 25 ${ }^{\circ} \mathrm{C}$ temperature with free access to food and water. All the experiments on animals followed the National Institutes of Health criteria for the care and use of laboratory animals. The study was also approved by the Laboratory Animal Care Committee of Sun Yat-sen University (Guangzhou, China).

\section{Quantitative analysis of NF-KB activity}

MIApaCa 2 cells were treated with $10-50 \mu \mathrm{M}$ of bryostatin 1 for 12,24 and $48 \mathrm{~h}$ and then analyzed for the expression of NF-kB p65. Following incubation, nuclear extract kit (Carlsbad, CA, USA) was used to prepare the extract of the nuclear material as per the manual instructions. The nuclear extract of the cells was then analyzed by enzyme-linked immunosorbent assay (ELISA) kit (TransAM ${ }^{\mathrm{TM}} \mathrm{NF}-\mathrm{kB}$; Active Motif). For this purpose, $5 \mu \mathrm{g}$ samples of the nuclear material were incubated with oligonucleotide containing NF-kB p65-binding sequence for a period of $45 \mathrm{~min}$ at $30{ }^{\circ} \mathrm{C}$ in a microwell. The nucleoplasm samples were then incubated with rabbit anti-NF-KB p65 antibodies (Qiagen, TX, USA) for $45 \mathrm{~min}$ at $30{ }^{\circ} \mathrm{C}$, followed by peroxidase-conjugated goat anti-rabbit IgG (Qiagen, TX, USA) for $45 \mathrm{~min}$ at $30{ }^{\circ} \mathrm{C}$. Tetramethylbenzidine reaction was used for the visualization of peroxidase activity and the optimal density was measured at $465 \mathrm{~nm}$.

\section{Cell proliferation assay}

The standard 3 (4, 5 dimethylthiazol 2 yl) 2,5 diphenyltetrazolium bromide assay was used for the analysis of inhibition of proliferation in pancreatic carcinoma cells. The cells were treated with bryostatin 1 at various concentrations $(10,20,30,40$ and $50 \mu \mathrm{M})$ for various time periods or with DMSO alone as the control. The density of the bryostatin 1- and DMSO treated cells was compared to determine the rate of cell proliferation inhibition by bryostatin 1.

\section{Western blot analysis}

MIApaCa 2 cells after incubation with bryostatin 1 were washed with PBS and treated with lysis buffer (Beyotime). The concentration of the proteins in the cell lysates was measured by Bradford method using bovine serum albumin as standard. $5 \mathrm{mg}$ samples of the proteins were loaded into $10 \%$ SDS-polyacrylamide gels and subjected to electrophoresis using constant 
voltage. The proteins were then transferred onto PVDF membranes (Millipore, Bedford, MA, USA). The non-specific sites in the membrane were blocked by incubation with blocking buffer (5 \% skim milk in TBS-T) for $3 \mathrm{~h}$ at room temperature. The membrane was then incubated with pro- and cleaved caspase-8, IKB - and phosphorylated IKB. monoclonal antibodies (Santa Cruz Biotechnology, Inc.) at $4{ }^{\circ} \mathrm{C}$ overnight. The membranes were washed three times with TBS-T and then incubated with a secondary antibody (Santa Cruz Biotechnology, Inc.) at room temperature for $1 \mathrm{~h}$. The immunoreactive bands were visualized using enhanced chemiluminescence kits (Pierce Biotechnology Inc., Rockford, IL, USA). Blots were stained with anti- $\beta$-actin or -GAPDH antibody (Santa Cruz Biotechnology, Inc.) as an internal control for the amounts of target proteins.

\section{Cell cycle analysis}

MIApaCa 2 cells were distributed at a density of $3 \times 10^{6}$ cells per well in 6 -well plates at $37^{\circ} \mathrm{C}$ and incubated with bryostatin 1. After incubation for $48 \mathrm{~h}$, the cells were washed with PBS, resuspended with $200 \mu \mathrm{L}$ RNase A (1 mg/mL) and $\mathrm{PI}(200 \mu \mathrm{g} / \mathrm{mL})$ (Beyotime, Haimen, China) for staining the DNA content. Following incubation for $30 \mathrm{~min}$ at room temperature in the dark, the cellular DNA was analyzed by FACSCalibur flow cytometer. ModFitLT V2.0 software (both from Becton-Dickinson) was used for the analysis of the data.

\section{Preparation of pancreatic xenograft cancer model}

$3 \times 10^{5}$ MIApaCa 2 cells suspended in $100 \mu \mathrm{l}$ volume of PBS were injected into the mice on
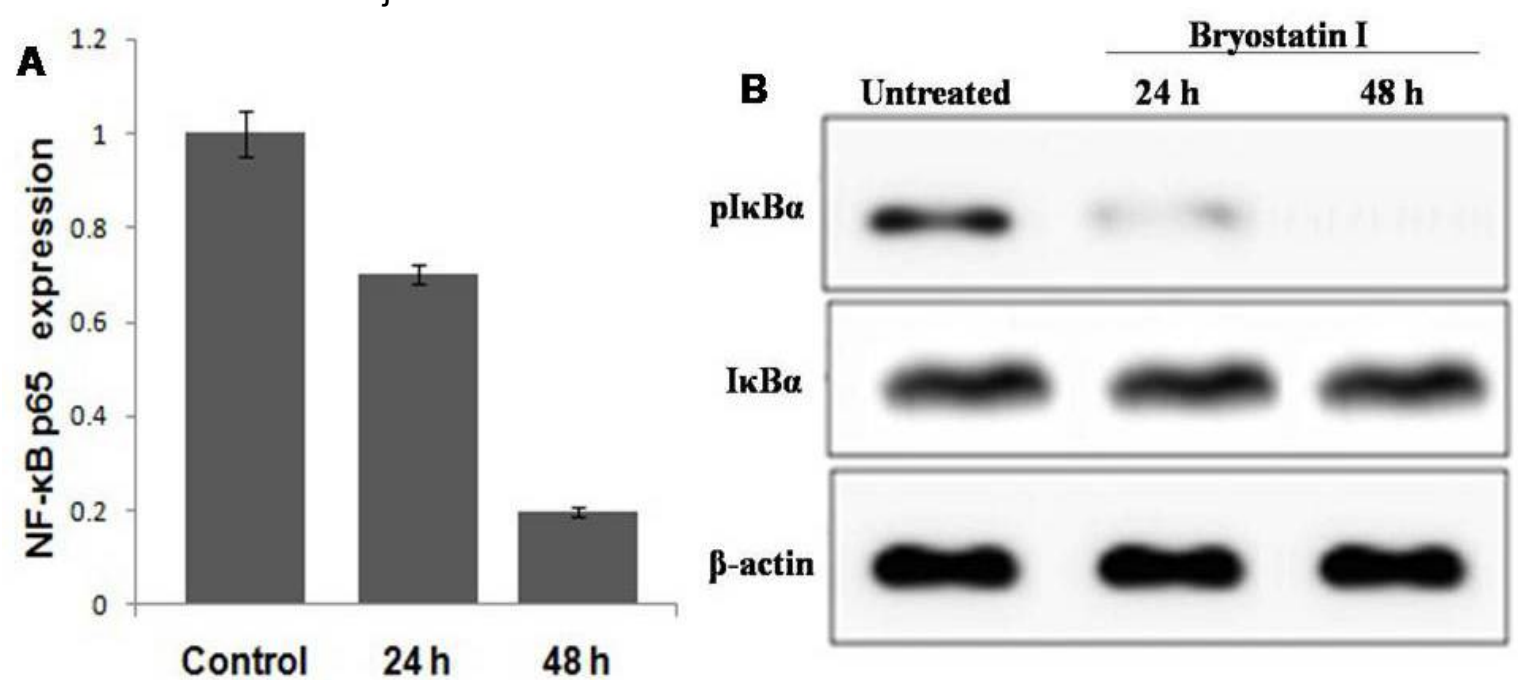

Figure 1: (A) Effect of bryostatin I on NF-KB p65 expression in MIApaCa-2 cell nuclear extracts; (B) Effect of bryostatin I on phosphorylated IKB using western blot analysis right dorsal side of the body. The animals were then randomly divided into the two groups of 15 animals each (treatment and untreated groups). The animals in the treatment group were injected $50 \mu \mathrm{g} / \mathrm{kg}$ body weight doses of bryostatin 1 dialy for 1 month in the morning whereas those in the untreated group received equal volume of normal saline. Five animals from each of the group were sacrificed after 30, 60 and 90 days following administration of MIApaCa 2 cells. The tumors mass from each of the animal was extracted, washed and weighed.

\section{Statistical analysis}

The results are expressed as mean \pm standard deviation (SD). For statistical analysis, SPSS 16.0 software was used. Comparison of the results was performed using one-way analysis of variance (ANOVA) and Student-Newman-Keuls test. Differences were considered statistically significant at $p<0.05$.

\section{RESULTS}

\section{Effect of bryostatin I on NF-KB activity}

Treatment of the MIApaCa 2 cells with bryostatin I caused a significant reduction in the activity of $\mathrm{NF}-\mathrm{KB}$ in nucleoplasm compared to untreated cells $(p=0.0002$, Fig. $1 \mathrm{~A})$. Bryostatin I treatment markedly inhibited the activation of $\mathrm{I} \mathrm{KB}$ in MIApaCa 2 cells after $48 \mathrm{~h}$ compared to untreated cells (Fig. 1B). It was observed that the level of activated IKB in bryostatin I treated MIApaCa 2 cells was significantly lower than those in untreated cells. 


\section{Bryostatin I Inhibits proliferation of MIApaCa-2 cells}

The results from MTT assay revealed that bryostatin I exhibited concentration and time dependent inhibitory effects on the proliferation of MIApaCa-2 cells. Increase in concentration of bryostatin I from 10 to $50 \mu \mathrm{M}$ reduced the percentage of MIApaCa-2 cell proliferation from 87 to $26 \%$ (Fig. 2). The rate of proliferation in MIApaCa-2 cells on treatment with $50 \mu \mathrm{M}$ bryostatin I after 12, 24 and $48 \mathrm{~h}$ was found to be $91.23 \pm 6.11,43.89 \pm 3.45$ and $26.14 \pm 2.67 \%$, respectively (Fig. 2).

\section{Bryostatin I induced apoptosis in MIApaCa-2 cells}

Bryostatin I treatment led to the increase in proportion of cells in M1 phase compared to the untreated cells (Fig. 3A). However, the proportion of cells in sub-G1 phase of cell cycle was reduced by bryostatin I treatment. Examination of the cell lysates revealed higher expression level of cleaved caspase-8 in the bryostatin I treated MIApaCa-2 cells compared to untreated cells (Fig. 3B).

\section{Bryostatin I treatment inhibits tumor growth in vivo}

Comparison of the tumor growth in bryostatin I treated and untreated mice after 2 months revealed a significantly lower tumor volume in treatment group than in untreated group (Fig. 4a). The average tumor volumes in the treatment and untreated groups were found to be $5.34 \pm$ 2.16 and $19.45 \pm 5.71 \mathrm{~mm}$, respectively after 2 months of the treatment period $(p<0.0002)$ (Fig. $4 A)$. The average weight of the tumors in the treatment and untreated groups were $123.67 \pm$ 22.56 and $939.14 \pm 213.51 \mathrm{mg}$, respectively after 2 months of the treatment (Fig. 4B).

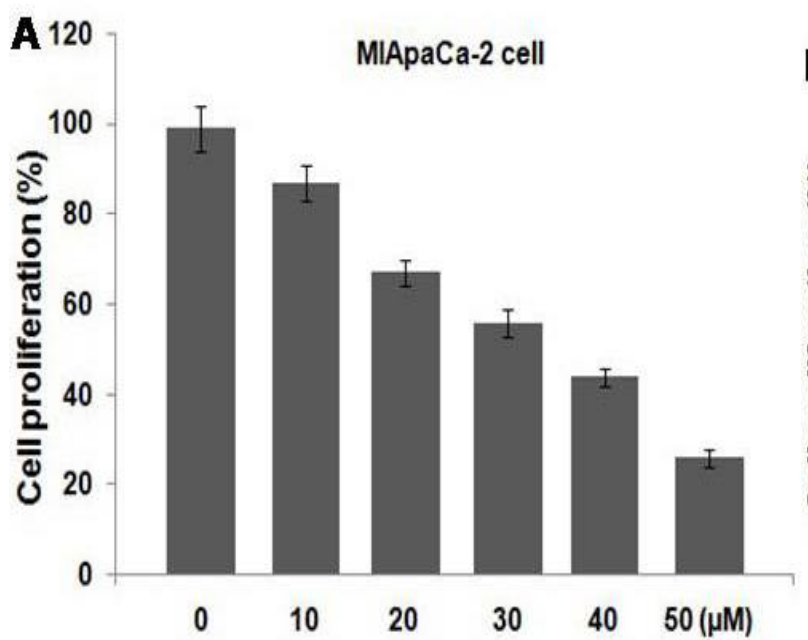

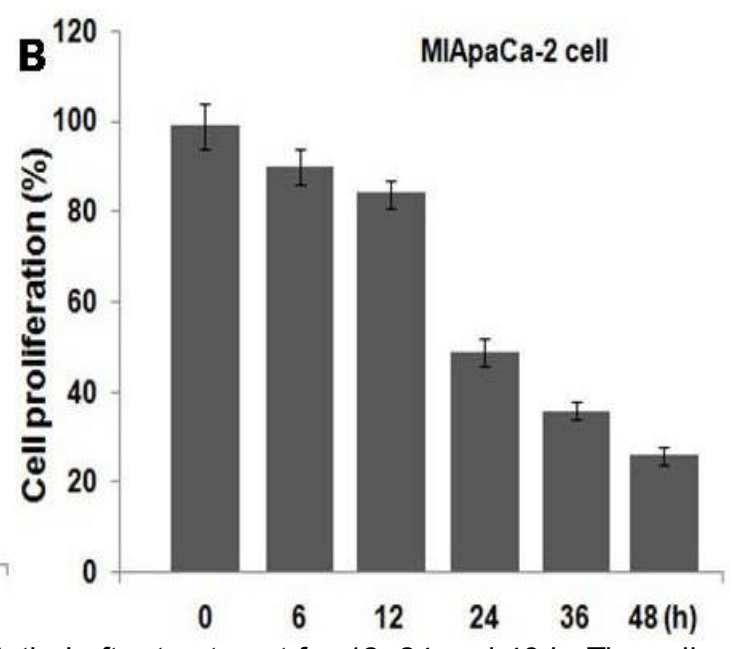

Figure 2: Inhibition of MIApaCa-2 cell viability by bryostatin I after treatment for 12,24 and $48 \mathrm{~h}$. The cells were incubated with 10 to $50 \mu \mathrm{M}$ concentrations of bryostatin I for 12,24 and $48 \mathrm{~h}$ and then analyzed by MTT assay
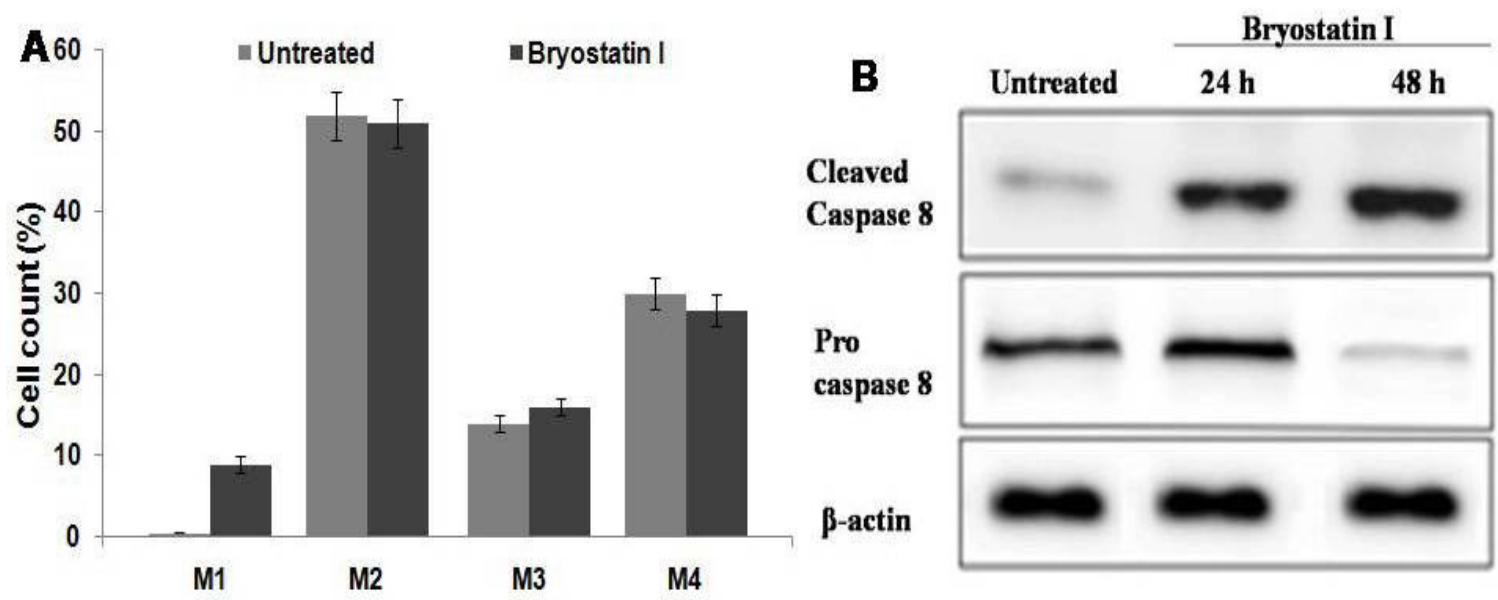

Figure 3: (A) Bryostatin I treatment increases the proportion of cells in the M1 phase with subsequent reduction in the sub-G1 phase of cell cycle; (B) Bryostatin I treatment enhanced the expression of pro-caspase- 8 in MIApaCa-2 cells 

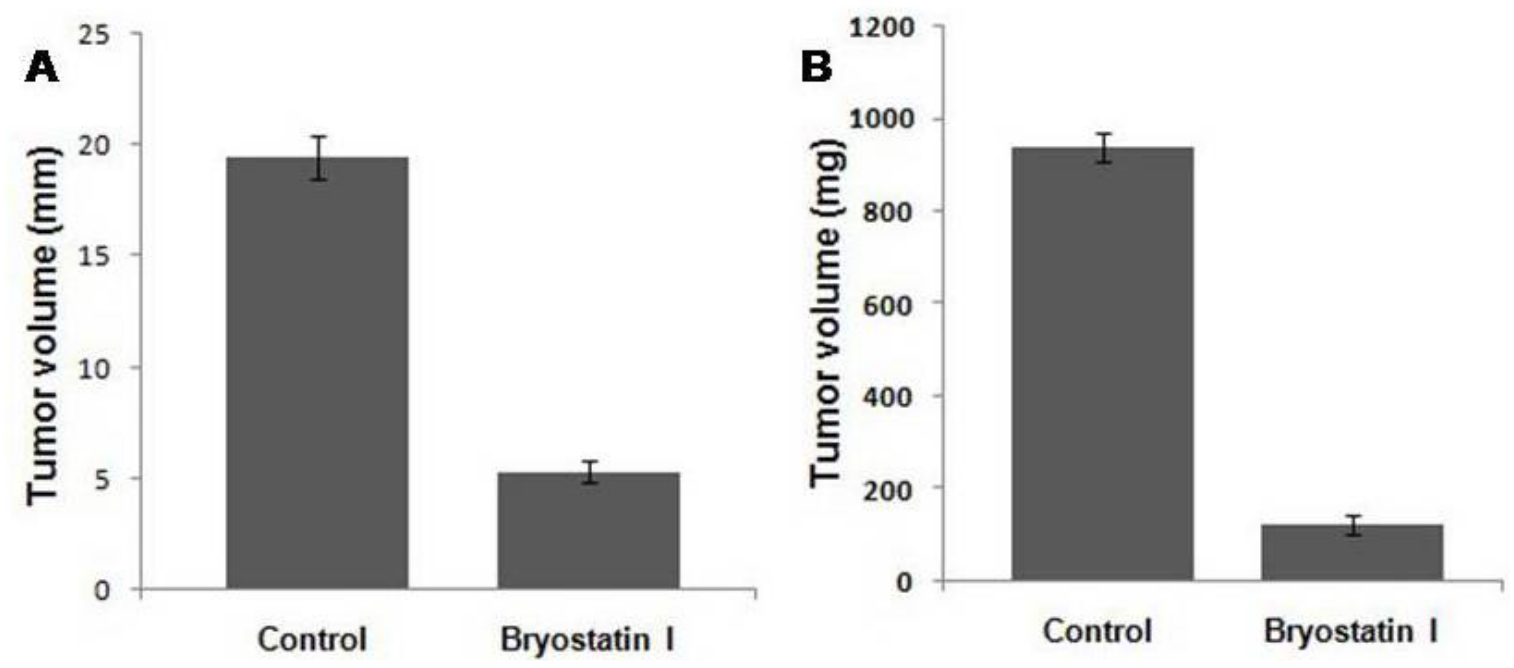

Figure 4: (A) Bryostatin I inhibited tumor growth in the MIApaCa-2 cell tumor xenograft model; (B) tumor weights in bryostatin I-treated group were significantly lower than those in control group

\section{DISCUSSION}

The present study investigates the effect of bryostatin I on proliferation of pancreatic cancer cells as well as tumor growth in mice tumor xenograft model. The study revealed that bryostatin I treatment results apoptosis in pancreatic carcinoma cells and inhibits growth of tumor in vivo by preventing the expression of NF$\mathrm{KB}$. The genes associated with the expression of proteins involved in the cellular processes, including apoptosis and inflammation are regulated by NF-KB expression. It is known that activation of NF-KB is inhibited during the process of inflammation [20,21]. The chemotherapeutic inhibition of NF-KB expression prevents proliferation, invasion and metastasis of cells in various types of cancers [22-24]. Although, a number of agents have been identified which play an important role in the inhibition of NF-KB expression. However, most of these agents induce harmful side effects [25]. Therefore, the discovery of the molecules which can inhibit the expression of NF-KB without side effect is highly desired. Our results from the current study revealed that bryostatin I treatment inhibited the expression of NF-kB in the pancreatic carcinoma cells. The level of activated IKB in MIApaCa 2 cells was reduced markedly on treatment with bryostatin I. Inhibition of carcinoma cell proliferation by the use of various agents plays important value in the treatment of cancer. The present study revealed that bryostatin I treatment caused a significant inhibition in the rate of proliferation in pancreatic carcinoma cells. Bryostatin I treatment in pancreatic cells resulted cell cycle arrest by increasing proportion of cells in M1 phase and subsequent reduction in sub-G1 phase of cell cycle. Western blot analysis showed significantly higher expression level of cleaved caspase-8 in the bryostatin I treated Panc-1 cells compared to untreated cells. Thus, bryostatin I induced apoptosis in pancreatic carcinoma cells through caspase-dependent pathway. Comparison of the tumor growth in bryostatin I treated and untreated mice after 2 months revealed a significantly lower tumor volume in treatment group than in untreated group.

\section{CONCLUSION}

The findings of this study indicate that bryostatin I induces apoptosis in pancreatic carcinoma cells and inhibits tumor growth in vivo through downregulation of NF-KB expression. Therefore, bryostatin I may be of therapeutic value for the treatment of pancreatic cancer.

\section{DECLARATIONS}

\section{Acknowledgement}

The authors are thankful to Head of the Department of Gastroenterology for generous support.

\section{Conflict of Interest}

No conflict of interest associated with this work.

\section{Contribution of Authors}

The authors declare that this work was done by the authors named in this article and all liabilities pertaining to claims relating to the content of this article will be borne by them.

Trop J Pharm Res, October 2016; 15(10): 2075 


\section{REFERENCES}

1. Matsuno S, Egawa S, Fukuyama S. Pancreatic Cancer Registry in Japan: 20 years of experience. Pancreas 2004; 28: 219230.

2. Schmidt CM, Powell ES, Yiannoutsos CT, Howard TJ, Wiebke EA, Wiesenauer CA. Pancreaticoduodenectomy: a 20 year experience in 516 patients. Arch Surg 2004; 139: 718727.

3. Höhne MW, Halatsch ME, Kahl GF, Weinel RJ. Frequent loss of expression of the potential tumor suppressor gene DCC in ductal pancreatic adenocarcinoma. Cancer Res 1992; 52: 26162619.

4. Niederhuber JE, Brennan MF, Menck HR. The National Cancer Date Base report on pancreatic cancer. Cancer 1995; 76: 1671-1677.

5. Chen F, Castranova V, Shi $X$. New insights into the role of nuclear factor- $K B$ in cell growth regulation. $A m \mathrm{~J}$ Pathol 2001; 159: 387-397.

6. Amer BA, David B. An essential role for $N F-K B$ in preventing TNF-alpha-induced cell death. Science 1996; 274: 782-784.

7. Huang $S$, Robinson JB, DeGuzman A, Bucana $C D$, Fiddler IJ. Blockade of nuclear factor-KB signaling inhibits angiogenesis and tumorigenicity of human ovarian cancer cells by suppressing expression of vascular endothelial growth factor and interleukin 8. Cancer Res 2000; 60: 5334-5339.

8. Matsumoto G, Namekawa J, Muta M, Nakamura T, Bando H, Tohyama K, Toi M, Umezawa K. Targeting of nuclear factor $K B$ pathways by Dehydroxymethyleoxyquinomicin, a novel inhibitor of breast carcinomas: antitumor and antiangiogenic potential in vivo. Clin Cancer Res 2005; 11: 1287-1293.

9. Wang W, Abbruzzese JL, Evans DB, Larry L, Cleary KR, Chiano PJ. The nuclear factor-KB RelA transcription factor is constitutively activated in human pancreatic adenocarcinoma cells. Clin Cancer Res 1999; 5: 119127.

10. Wang W, Abbruzzese JL, Evans DB, Chiano PJ. Overexpression of urokinase-type plasminogen activator in pancreatic adenocarcinoma is regulated by constitutively activated RelA. Oncogene 1999; 18: 45544563.

11. Cross TG, Scheel-Toellner D, Henriquez NV, Deacon E, Salmon M, Lord JM. Serine/threonine protein kinases and apoptosis. Exp Cell Res 2000; 256: 34-41.

12. Aggarwal BB, Takada Y. Pro-apoptotic and anti-apoptotic effects of tumor necrosis factor in tumor cells. Role of nuclear transcription factor NF-KB. Cancer Treat Res 2005; 126: 103-127.

13. Graham B, Gibson SB. The two faces of NF-KB in cell survival responses. Cell Cycle 2005; 4: 1342-1345.
14. Pettit GR. The bryostatins. Fortschr Chem Org Naturst. 1991; 57: 153-195.

15. Pagliaro L, Daliani D, Amato $R$, et al. Phase II trial of bryostatin-1 for patients with metastatic renal cell carcinoma. Cancer. 2000; 89: 615-618.

16. Varterasian ML, Mohammad RM, Shurafa MS, et al. Phasell trial of bryostatin I in patients with relapsed lowgrade non-Hodgkin's lymphoma and chronic lymphocytic leukemia. Clin Cancer Res. 2000; 6: 825828.

17. Zonder JA, Shields AF, Zalupski M. A phase II trial of bryostatin 1 in the treatment of metastatic colorectal cancer. Clin Cancer Res. 2001; 7: 38-42.

18. Ahmad I, Al-Katib AM, Beck FW, Mohammad RM. Sequential treatment of a resistant chronic lymphocytic leukemia patient with bryostatin I followed by 2chlorodeoxyadenoside: case report. Clin Cancer Res. 2000; 6: 1328-1332.

19. National Institute of Health. USA. Public health service policy on human care and use of laboratory animals, 2002.

20. Tsuzuki H, Tani T, Hanazawa K. Regulation of NF-KB. lyakunomonn 2003; 43: 162-167(in Japanese).

21. Chen CL, Wang SD, Zeng ZY BSc, Lin KJ, Kao ST, Tani $T$, Yu CK, Wang JY. Serine protease inhibitors nafamostat mesilate and gabexate mesilate atteneuate allergen-induced airway inflammation and eosinophilia in a murine model of asthma. J Allergy Clin Immunol 2006; 118: 105-112.

22. Kimura $T$, Fuchimoto $S$, Iwagaki $H$, Hizuta $A$, Orita $K$. Inhibitory effect of nafamoatat mesilate on metastasis into the livers of mice and on invasion of the extracellular matrix by cancer cells. J Int Med Res 1992; 20: 343-352.

23. Ohta T, Shimizu K, Yi S, Takamura H, Amaya K, Kitagawa $H$, Kayahara $M$, Ninomiya I, Fushida $S$, Fujimura T, Nishimura G, Miwa K. Protease-activated receptor-2 expression and the role of trypsin in cell proliferation in human pancreatic cancers. Int $\mathrm{J}$ Oncol 2003; 23: 61-66.

24. Tajima $H$, Ohta $T$, Elnemr $A$, Yasui $T$, Kitagawa $H$, Fushida S, Kayahara M, Miwa K, Wakayama T, Iseki S, Yokohama S. Enhanced invasion of pancreatic adenocarcinoma cells stably transfected with cationic trypsinogen cDNA. Int J Cancer 2001; 94: 699-704.

25. Richardson PG, Barlogie B, Berenson J, Singhal $S$, Jagannath S, Irwin D, Rajkumar SV, Srkalovic G, Alsina $M$, Alexanian $R$, Siegel $D$, Orlowski $R Z$, Kuter $D$, Limentani $S A$, Lee $S$, Hideshima $T$, Esseltine $D L$, Kauffman M, Adams J, Schenkein DP, Anderson KC: A phase 2 study of bortezomib in relapsed, refractory myeloma. N Engl J Med 2003; 348: 2609-2617. 